\title{
Forecast Analysis of Potential and Availability in Renewable Energy
}

\author{
Kavita S. Jerath, N. K. Millerjothi, S. Karthiyayini, and Akshay Sharma
}

\begin{abstract}
Gulf Cooperation Council (GCC) founded on $\mathbf{2 6}^{\text {th }}$ May 1981 is a collective of six countries or nations Bahrain, Kuwait, Oman, Qatar, Saudi Arabia and UAE. The GCC countries with their growing population require more energy for basic needs. Almost 99\% of power generation in GCC is from oil and natural gas but as most of the countries are largely committed to the export of these commodities, now they are facing domestic shortage for power generation. The expected period of lasting oil reserves in the GCC differs between states and the countries with shorter oil production ability require urgent diversification policies. Ample availability of mainly solar and wind energy along with the capacity to invest, offers GCC significant opportunities to become a leader in the renewable energy industries. GCC has established a Centre of Excellence in Renewable Energy Research in the gulf region with a presence in each of its six states. It focuses mainly on promoting scientific and technological development in renewable energy sector, increasing public awareness, enhancing knowledge and technology transfer. This paper presents a review of potential renewable energy sources and projects in GCC.
\end{abstract}

Index Terms - Bio fuel, geothermal, energy, solar, wind.

\section{INTRODUCTION}

Gulf Cooperation Council (GCC) over the past three decades has witnessed tremendous social and economic transformations. In 1970s GCC countries started developing their infrastructure by building roads, hospitals, public utilities and schools from oil revenues. In 1974 and 1981 oil price almost doubled followed by another oil boom in 2005 . This marked a new phase of economic development and growth in GCC. Also the export of oil brought in surplus cash which exceeded their requirements. The fast growing economies of GCC forced countries to utilize their natural gas resource as well. . But in 2009 due to the global financial crisis, the Arab world faced major decline in the energy sector investment. Most of the national oil companies rescheduled their projects. By the time remaining oil and gas production for GCC had started declining. Thus it became necessary to look into new sources of energy [1].

Renewable energy describes energies which come from natural resources like sunlight, wind, tides, waves and geothermal heat, which will not run out ever and do not harm our environment. It is energy efficient, ensures energy security and economic benefits. Renewable energy is an

Manuscrpit received June 14, 2014; revised August 11, 2014.

Kavita S. Jerath and Akshay Sharma are with Bits Pilani Dubai, DIAC, Dubai (e-mail: genesis1905@gmail.com).

N. K. Millerjothi is with the Department of Mechanical Engineering, Bits Pilani Dubai (e-mail: millerjothi@dubai.bits-pilani.ac.in).

S. Karthiyayini is with the Department of Physics, Bits Pilani Dubai. alternative for conventional fuels in four areas: generation of electricity, hot water or space heating, motor fuels and rural energy services. Some of the advantages and disadvantages of using renewable energy sources are given below:

- Advantages include

1) Sustainable

2) Less maintenance and operating cost than traditional generators

3) Produce little or no pollution

4) Economic benefits

- Disadvantages include

1) Difficult to produce large quantities of power

2) More energy facilities needed

3) Unpredictable and inconsistent availability of sources

4) High capital cost

\section{Renewable Potential in the Middle East}

There is a large potential for renewable resources in the Middle East which, up to this point, have remained largely untapped. This is especially true of solar power; its potential in the Middle East North Africa (MENA) region alone far exceeds global electricity demand. The earth receives an incredible supply of solar energy - the sun provides enough energy in one minute to supply the world's energy needs for a full year. In one day it provides more energy than our current population would consume in 27 years [2].

According to a report by the Electrical Engineering Department at King Saud University, the Middle East receives 3,000 - 3,500 hours of sunshine per year, with more than $5.0 \mathrm{~kW} / \mathrm{m}^{2}$ of solar energy per day.

\section{Why INVEST IN RENEWABLE ENERGY IN MENA REGION}

Energy demand is expected to continue to rise in MENA above the world average from 2010 to 2030. Energy consumption in MENA has risen on average by $5.2 \%$ a year since 2000. Demand for electricity is further spurred by a growing population, increasing at a regional average of around $2 \%$ a year since 2008 .

- Renewable energy creates much needed jobs:

1) To produce the equivalent quantity of megawatt hours, solar photovoltaic plants use on average seven times more labor than coal-fired plants according to the UN.

2) Wind power uses on average 1.83 times more labor than natural gas.

- Renewable energy contributes to economic and inclusive growth by:

1) Encouraging the transfer of skills and technology from foreign investors. 
2) Bringing electricity to rural and under-developed areas.

3) Increasing women's economic empowerment [2].

\section{COUNTRY Wise OVERVIEW}

The Pie charts shows about the availability of various renewable energy being used in the GCC countries.

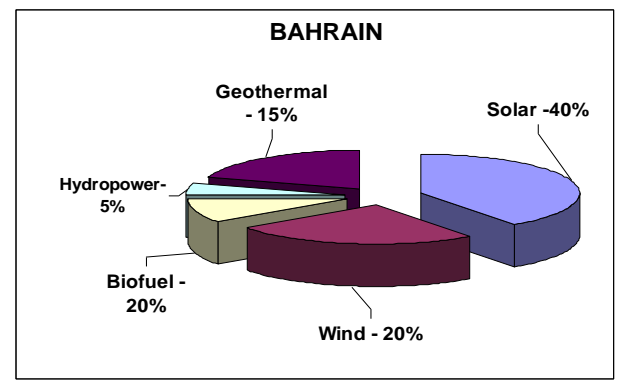

Fig. 1. Availability of renewable energy in Bahrain.

The potential and availability of renewable energy in Bahrain is shown in Fig. 1. It can be seen that solar energy has the highest percentage as the strategically located Bahrain receives ample sunlight all the time.

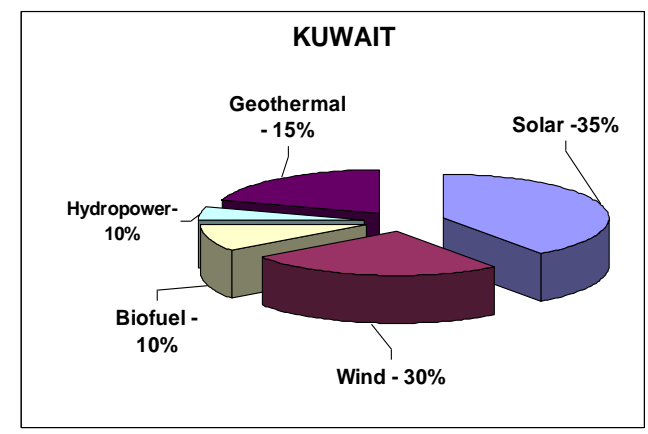

Fig. 2. Availability of renewable energy in Kuwait.

The availability of renewable energy in Kuwait is shown in Fig. 2. It is observed that solar and wind energy has the highest percentage as the climate conditions favor high gusts of wind and solar.

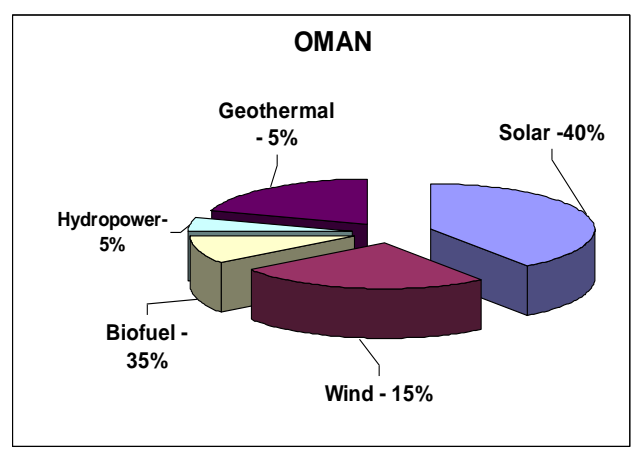

Fig. 3. Availability of renewable energy in Oman.

Fig. 3 shows the availability of renewable energy in Oman and compared with potential of other renewable energy. It can be noticed that solar and biofuel has the highest percentage of availability as Oman's hydrocarbons sector accounted for $86 \%$ of government revenues.

Fig. 4 depicts the availability of renewable energy in Qatar and compared with solar and potential of other renewable energy. It is observed that bio-fuel has the highest percentage of availability in Qatar as the electricity generation capacity has an annual growth rate of $70 \%$.

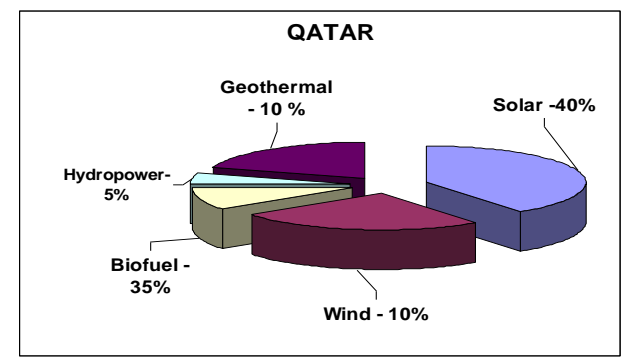

Fig. 4. Availability of renewable energy in Qatar.

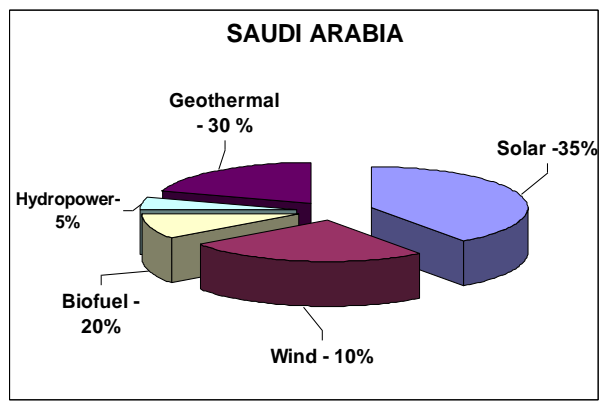

Fig. 5. Availability of renewable energy in Saudi Arabia.

The potential and availability of renewable energy in Saudi Arabia is shown in Fig. 5. It can be found that solar, geothermal are the maximum as the annual sunshine on Saudi is extremely high which supports the former as well as the latter.

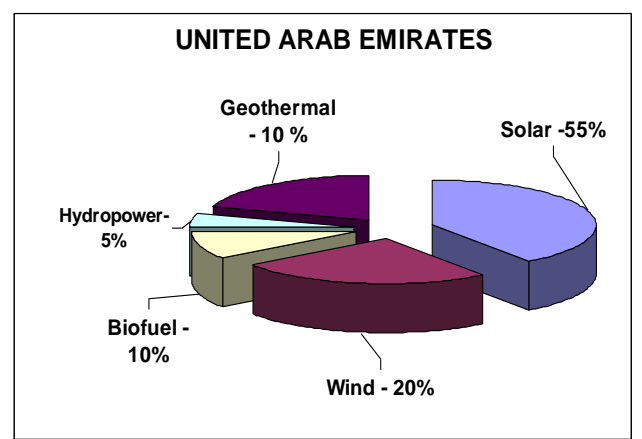

Fig. 6. Availability of renewable energy in UAE.

The variation and availability of renewable energy in UAE is depicted in Fig. 6. It can be seen that solar power generation has the highest percentage as receives ample sunlight all the time.

\section{RENEWABLE ENERGY PROJECTS-GOVERnMENT SECTOR}

\section{A. Bahrain}

Since 1990s research was conducted by University of Bahrain (UoB) for utilizing renewable energy sources. Various demonstration projects and public awareness

1) In 2007 , three parallel wind turbines having capacity of $0.66 \mathrm{MW}$ were installed in Bahrain.

2) In 2008, Electricity and Water Authority (EWA) formed a committee consisting of Industry and Commerce Ministry, National Oil and Gas Authority (NOGA), Bahrain Petroleum Company (BAPCO), Alba, UoB and 
Public Commission for Protection of Marine Resources, Environment and Wildlife. They made plans for the establishment of two solar and wind energy projects by 2012.

3) In 2010, a $25 \mathrm{MW}$ waste-to-energy plant was planned in Askar. It was commissioned to France's Construction Company on a build-operate-transfer basis and is expected to start operating in 2013.

4) In 2011, BAPCO and German Heliocentris installed an energy system of $5 \mathrm{KW}$ capacity that receives input from a $4 \mathrm{KW}$ photovoltaic (PV) and $1.7 \mathrm{KW}$ wind generator. Energy produced is stored by generating hydrogen which is then converted into electricity by a $1.2 \mathrm{KW}$ fuel cell [3]-[6].

\section{B. Kuwait}

Kuwait being the fourth largest oil exporter in the world is now facing serious domestic electricity demand. Its aim is to produce $5 \%$ of total energy demand from renewable energy sources. Many public awareness and workshop programs are undertaken by the government.

1) In 2008, Sabah Al Ahmed International Financial Center, Kuwait's first gold LEED building was open. The building uses PV panels and wind turbines for electricity generation.

2) In 2011, Ministry of Electricity and Water (MEW) planned to develop a $70 \mathrm{MW}$ renewable energy electricity complex at Abdeli. It comprises of $10 \mathrm{MW} \mathrm{PV}$ panels, $10 \mathrm{MW}$ wind farm and $50 \mathrm{MW}$ concentrated solar power (CSP) using trough concentrators.

3) Kuwait Oil Company came up with two pilot solar power schemes. First scheme is for the construction of 5 MW PV plant followed by second scheme for CSP plant to produce electricity and steam for enhanced oil recovery.

4) Ministry of Economy, Trade and Industry of Kuwait will develop the first combined cycle project of capacity 280 MW consisting of 54 solar trough collectors which contributes $60 \mathrm{MW}$ combined with cycle gas turbine of capacity $220 \mathrm{MW}$.

5) Kuwait Ministry of Electricity and Water is planning of installing $1 \mathrm{MW}$ solar PV panels on rooftops of two of its buildings, MEW and Ministry of Public works (MPW).

6) Civil Aviation Authority aims at building world`s first LEED Gold certified airport terminal [7], [8].

\section{Oman}

According to Oman Power and Water Procurement Company (OPWPC) the peak demand for water and electricity reached 3,856 MW in 2010 which is a $46.4 \%$ increase since 2005 . In fact electricity demand is expected to rise in future due to growing population and government policy for economic diversification which has led to increasing establishment of industrial and touristic projects all over Oman.

1) In 2008 International consultants COWI and Partners LLC., were commissioned by the regulatory authority to study and identify the renewable sources. Significant solar and wind energy potentials were identified and developers were invited by the authority for small scale pilot projects to confirm the performance and efficiency of renewable energy technologies under local conditions. The locations were supplied by Rural Areas Electricity Companies (RAEC). From the proposals the authority confirmed a shortlist of 6 pilot projects out of which two projects were for immediate implementation

a) $500 \mathrm{KW}$ wind energy project in Masirah Island

b) $100 \mathrm{KW}$ photovoltaic (PV) solar project in Hij

Four projects for implementation after further discussion with developer

a) $4200 \mathrm{KW}$ wind energy project in Saih Al Khairat

b) $292 \mathrm{KW}$ solar energy project in Al Mazyonah

c) $1500 \mathrm{KW}$ project at locations to be confirmed

d) $28 \mathrm{KW}$ solar energy project in Al Mathfa incorporating battery storage capacity.

2) In 2009, Public Authority for Electricity and Water took the initiative to build PV and CSP plant of capacity 200 MW at a cost of $\$ 600$ million. Plant will start functioning in 2013.

3) In 2011, Petroleum Development Oman commissioned Glass Point Solar to build $7 \mathrm{MW}$ solar thermal oil recovery plant. It would produce 11 tons $/ \mathrm{hr}$ of pressurized steam extracting 33,000 barrels of oil [9]-[12].

\section{Qatar}

Qatar is one of the fastest growing power markets in GCC. The peak demand for power had reached 5,500 MW in 2011. Between 2008 and 2010, Qatar`s electricity generation capacity has reached an annual growth rate of $70 \%$, which is more than that required by the country`s peak load demand. Taking advantage of this surplus, Qatar exported electricity on a commercial basis.

1) In 2006, Energy City Qatar (ECQ) was launched. It will consist of 92 corporate buildings, able to house approximately 20,000 people. All the buildings will be constructed at highest standard complying with US Green Building Council LEED Certification requirements for energy efficiency. All government buildings will have to conform to the green building standards by 2016 .

2) In 2008, Qatar General Electricity and Water Corporation or KAHRAMAA announced the construction of $3.5 \mathrm{GW}$ solar combined cycle which is expected to be completed in 2013. It will use CSP technology for electricity and water desalination.

3) In 2009 Qatar Solar Technologies came up with a plan to build 100 MW PV plant by 2014 and PV modules are likely to come from Qatar based polycrystalline Silicon production under QSTech.

4) In 2010, Qatar Airways along with Airbus, Qatar Petroleum and Qatar Science and Technology Park (QSTP) made a project called the Qatar Advanced Biofuel Platform. Its aim is to develop new aviation biofuels with the support of external collaborators from within the energy and aviation industries.

5) QSTP and Fraunhofer Institute took the initiative to produce hydrogen from solar energy and the project was named "Solar Carbon Black Project".

6) In 2011, KAHRAMAA announced that the company is going to build Qatar`s first solar powered desalination 
plant by 2013.

7) Qatar Environment and Energy Research Institute (QEERI) and Spanish Research Center for Energy, Environment and Technology have started with a pilot plant of $300 \mathrm{KW}$ [13], [14].

\section{E. Saudi Arabia}

In Saudi Arabia the power generation is reached 51.2 GW in 2009 and is expected to reach $53.3 \mathrm{GW}$ by 2020. The electricity generating capacity of Saudi Arabia has a preserve margin of $3 \%$, compared to a global average of $10 \%$. Demand has also sustained to exceed growth in supply leading the Saudi Electric Company to hold back supplies to some areas during peak demand times.

1) In 2008, King Abdullah University for Science and Technology (KAUST)-IBM initiated a joint research to develop novel membrane technology and ultra-high concentrator photovoltaic (UHCPV) that will help to power a $30,000 \mathrm{~m}^{3} /$ day solar desalination plant in $\mathrm{Al}$ Khafji. It is expected to be completed in 2013.

2) Solar desalination using adsorption process is jointly studied by KAUST Water Desalination and Reuse Center and the National University of Singapore. It uses solar thermal evaporation process.

3) In 2010, ARAMCO commissioned Phoenix Solar AG and Naizak Global Engineering to build a 3.5 MW solar plant in Dhahran next to King Abdullah Petroleum Studies and Research Center.

4) In 2011, a pilot plant with $500 \mathrm{KW}$ capacities was planned to be implemented under the cooperation agreement of Saudi Electricity Company and Shoya Shell using Copper-Indium-Selenium panels.

5) Saudi Arabia is investing around $\$ 100$ billion for $5 \mathrm{GW}$ solar energy plant to be completed by 2020 [15]-[17].

\section{F. United Arab Emirates}

UAE is a collective of seven emirates: Abu Dhabi, Dubai, Sharjah, Fujairah, Ajman, Ras al-Khaimah and Umm al-Quwain. Peak demand for electricity in Abu Dhabi alone has reached 6,885 MW in 2010 and is expected to be 11,200 MW by 2015. Also they export electricity to other emirates through their electricity grid. Abu Dhabi has shown tremendous increase in investment and development of renewable energy technologies.

1) Masdar was established in 2006 and is a commercially driven enterprise that operates across the full spectrum of renewable energy technologies. In Masdar City building rooftops are installed with $1 \mathrm{MW}$ systems of SunPower E19 solar PV panels which provide 30\% of electricity for domestic needs. Remaining is met by a 10 MW solar PV plant built in 2009. Rooftop thermal collectors provide $75 \%$ of hot water requirement. Masdar city now consists of only Masdar Institute of Science and Technology (MIST) and its student residences. Abu Dhabi Future Energy Company aims at an urban planning that is energy efficient and from which world can learn.

2) A $100 \mathrm{MW}$ PV plant Noor 1 used Masdar PV company`s thin film modules having double layered amorphous silicon thin films with 3 junctions.

3) In 2007, Pacific Control Systems in Dubai was certified
LEED for using $50 \mathrm{KW}$ solar PV system for lighting and 100 tons of solar thermal energy for air conditioning.

4) Shams 1 CSP plant is a joint venture of Masdar, Abengoa Solar and Total S.A. expected to be completed in 2013 with a 100 MW capacity. Shams 1 is one of the world`s largest CSP power plant. It is located in Madinat Zayed, $116 \mathrm{Km}$ southwest of Abu Dhabi city. Shams 1 uses 258,048 parabolic trough mirrors, 192 solar collector assembly loops with 8 solar collector assemblies per loop, 768 solar collector units and 27,648 absorber tubes. Collector tubes temperature ranges from $293^{0} \mathrm{C}-393{ }^{0} \mathrm{C}$. Oil is used as the heat transferring medium and is circulated from solar field to power station turbine.

5) In Sir Baniyas Island, $250 \mathrm{Km}$ southwest of Abu Dhabi, an $850 \mathrm{KW}$ capacity Vestas wind turbine is installed. Masdar Power is also planning an onshore $30 \mathrm{MW}$ wind farm in Abu Dhabi.

6) In 2011 planning and development of Mohammad Bin Rashid Al Maktoum Solar Park and PV plant of capacity 10 MW was initiated in Dubai by Dubai Supreme Council of Energy at a cost of AED 12 billion [18]-[20].

\section{COUNTRY Wise ANALYSIS IN GCC}

\section{A. Demonstration Projects}

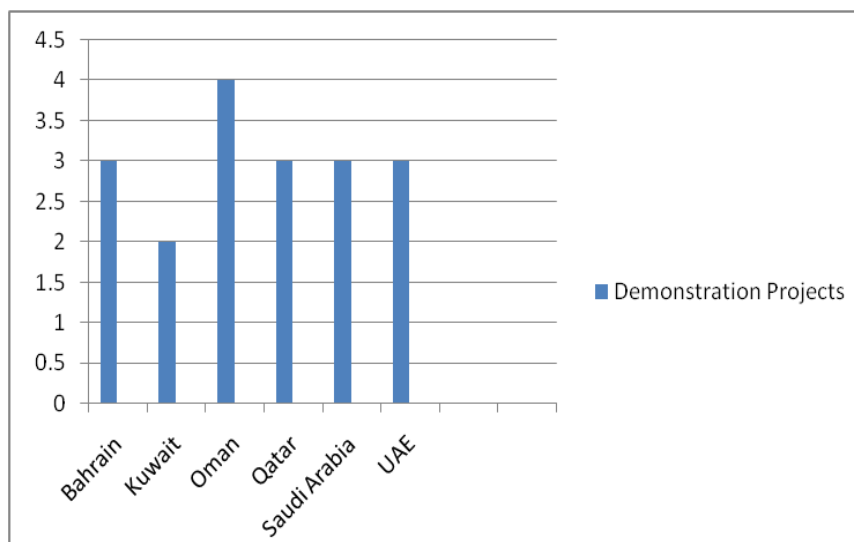

Fig. 7. Demonstration projects in GCC.

The demonstration projects of renewable energy in GCC are shown in Fig. 7. It can be noticed that Oman has the highest demonstration projects compared to other GCC. In Oman, a 9 MW diesel generator and 10 wind turbines of 900 KW each installed at Masirah Island. Ministry of water resources started a project on the use of brackish water for crop irrigation. It produced electricity by two $50 \mathrm{KW}$ diesel generators, water by PV solar desalination and a $10 \mathrm{KW}$ wind turbine was also installed by Oman Solar Systems.Oman is byfar the leading country in demonstration projects in GCC [21].

\section{B. Public Campaigning Projects}

Fig. 8 depicts the Public Campaigning Projects in Middle East. It is observed that UAE has the highest public campaigning projects compared to other countries. In 2006, Masdar Institute of Science and Technology was established in UAE. People are made aware through posters and TV ads 
which is a very good way to spread awareness. Awareness programs are conducted in schools and colleges. UAE is leading in public campaigning programs.

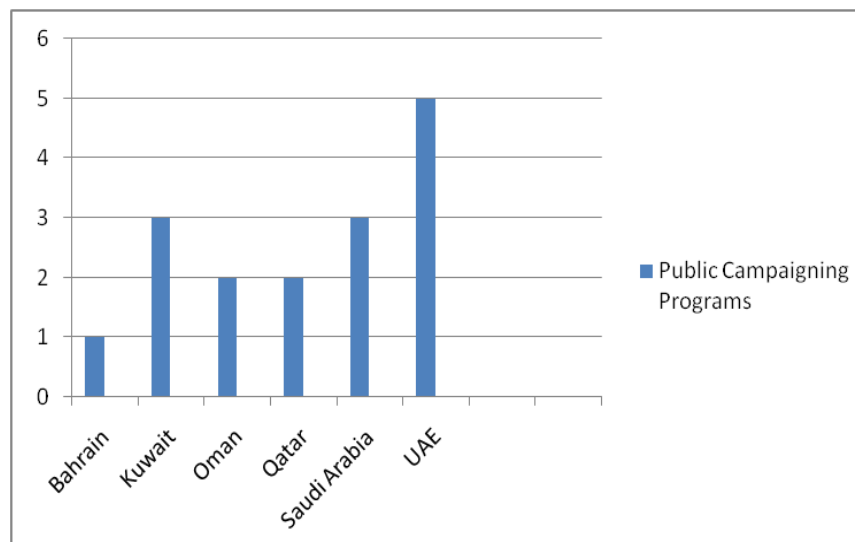

Fig. 8. Public campaigning projects in middle east.

\section{1) Renewable energy equipments manufactureres in GCC}

Number of renewable energy equipments manufactureres in GCC is shown in Fig. 9. From the figure it can be noticed that Saudi Arabia is the leading country for manufacturing of all kind of renewable energy equipments. Saudi Arabia has 14 companies which manufacture energy equipments. UAE comes second with 7 companies, followed by bahrain and kuwait with 4 each.

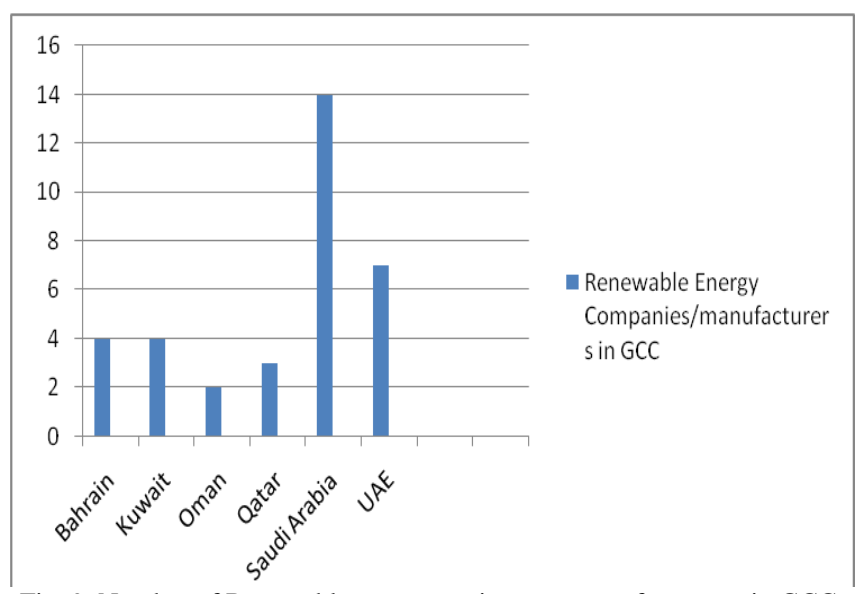

Fig. 9. Number of Renewable energy equipments manufactureres in GCC.

\section{2) Correlation between initiatives and current activities}

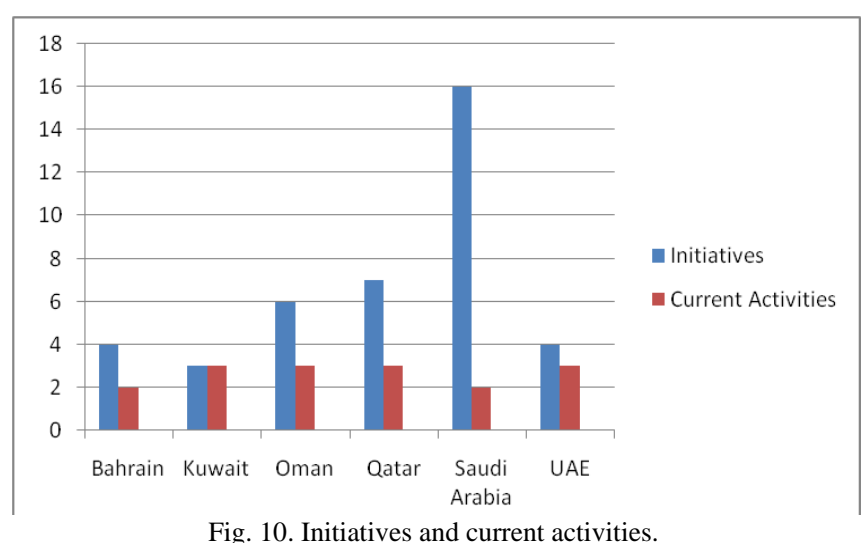

Correlation between Initiatives and Current Activities are compared with all countries in GCC are shown in Fig. 10. Saudi Arabia is investing the maximum in power sector and their current focus includes projects for 16 nuclear reactors and solar plants. Qatar is planning to erect 7 solar and wind plants. They are currently producing solar energy at a very impressive rate and are planning to use the same in the 2022 world cup.

\section{Potential Investments}

1) Bahrain government is planning to produce $5 \%$ of the total power from renewable sources by 2030.Investement of $\$ 900$ million is expected.

2) Kuwait is planning the same by 2020 . US $\$ 2.5$ billion is being invested.

3) Oman \& Qatar governments have not specified plans yet have invested \$800million and \$600million respectively.

4) Saudi Arabia is planning on producing a staggering $15 \%$ of the energy from renewable sources by 2020 and is investing $\$ 15$ billion.

5) UAE is planning on 5\% by 2030 and has invested $\$ 5.1$ billion.

\section{PRoBlems FACEd IN PROJECTS}

1) Performance in high-temperature and high-soiling environment.

2) CAPEX (Capital Expenditure) is high which causes hindrance in the project commissioning. OPEX (operational expenditure) is also a task to be dealt with.

3) Commercialization of the energy is a big task. The normal timeline between laboratory (small scale) experiment of feasibility and full extensive scale commercialization is twenty to twenty-five years.

4) Energy Return on Investment (EROI) is crucial. It should be as high as possible as the magnitude is a key indicator of its contribution to maintenance of social and economic complexity. Low in case of Solar energy as the energy input is higher than the output [22].

5) Uninterrupted supply of energy sources like wind and solar are mandatory for the continuous power generation. Sudden climate changes are a bit of a problem in the area.

\section{OVERCOMING PROBLEMS}

1) The development of solar-power electricity requires additional infrastructure; solar electricity must be generated where the best resources exist, which is often far from population centres.

2) Additional material costs need to be considered. Extensive investment in transmission infrastructure to bring it to consumption centres are required which should be kept in mind and the investment should be accordingly calculated.

3) Dust has a drastic impact on PV performance. Thus, the equipment should go through rigorous testing for sandblasting, environmental sealing, and corrosion.

4) Large Scale Batteries should be used to store the energy which later can be used. Thus no loss of energy is present 
[1], [23].

\section{REGULATORY BARRIERS}

\begin{tabular}{|c|l|}
\hline Country & \multicolumn{1}{|c|}{ Barriers } \\
\hline Bahrain & \multicolumn{1}{|c|}{ Lack of investment in renewable energy projects. } \\
\hline Kuwait & $\begin{array}{l}\text { (i) Reliance on oil as fuel and its revenue reduces } \\
\text { the utilization of renewable energy } \\
\text { (ii)Less involvement of public sector for investing } \\
\text { in projects. }\end{array}$ \\
\hline Oman & $\begin{array}{l}\text { (i) As per the geography of Oman, particularly the } \\
\text { mountainous north it is tough to distribute the } \\
\text { power generated. } \\
\text { (ii)Establishment of an agency to support } \\
\text { renewable energy and the creation of feed-in-tariff } \\
\text { system would provide incentives for projects. }\end{array}$ \\
\hline Qatar & $\begin{array}{l}\text { Reducing the current subsidies on electricity from } \\
\text { oil and gas would promote a fairer market for } \\
\text { renewable energy. }\end{array}$ \\
\hline Saudi Arabia & $\begin{array}{l}\text { The present cost of electricity in the country makes } \\
\text { the market competitive for renewable energy. }\end{array}$ \\
\hline UAE & $\begin{array}{l}\text { (i) Any company involved in investment should be } \\
\text { owned 50\% by one or more UAE nationals } \\
\text { (ii)Key bodies involved in renewable energy } \\
\text { projects in addition to municipal needs require } \\
\text { own permitting process. }\end{array}$ \\
\hline
\end{tabular}

\section{TRANSMISSION GRIDS FOR A GLOBAL IMPACT}

Electricity from renewable energy may be grid connected in order to reduce costs, increase reliability and security, and to encourage cooperation within the Middle East and with Europe. Transnational power lines are in the process of being developed, which renewable energies may easily tap into.

The multibillion-dollar Gulf States Cooperation Council (GSCC) power grid project is creating an integrated electricity network in the Middle East. This network will create 100,000 MW of additional power over the next 10 years to meet demand for an estimated $\$ 100$ billion dollars.

The states involved are Saudi Arabia, Qatar, Bahrain, Kuwait, Oman and the United Arab Emirates. Thirteen contracts will be awarded in the first phase, worth $\$ 1.25$ billion to link Saudi Arabia with Kuwait, Bahrain and Qatar. A partnership between the EU and MENA will greatly benefit both sides: MENA may utilize and export their vast solar resource for economic growth while the EU can provide the technologies and the capital to activate these potentials [21], [23], [24].

\section{CONCLUSION}

All countries in GCC are blessed with ambient solar and wind energy sources. In countries where large land areas are available hybrid plants combining renewable and conventional sources are found to be better solutions. But the use of alternative energy is still limited in GCC countries as demonstration projects have shown high cost compared with conventional power generation. As a result only renewable energy initiatives have taken place in most of the countries. Cutting subsidies and providing electricity at the real cost will help to make people aware and thus avoid excess use and wastage of electricity and water. The success of renewable energy technologies in GCC depends on introducing supporting policies such as binding targets and financial incentives, as well as regulatory frameworks to encourage deployment and reduce cost by each country.

\section{REFERENCES}

[1] Y. Al-Saleh and H. Taleb, "The integration of sustainability within value management practices: a study of experienced value managers in the GCC countries," Project Management Journal, vol. 41, no. 2, pp. 50-59, 2009.

[2] K. Amir and O. C. John, Renewable Energy across Middle East and North Africa (MENA Region), vol. 1, 2010.

[3] W. E. Alnaser and H. S. Almudiafa, "Calculation of the global, and direct solar radiation in Bahrain," Solar and Wind Techlogy, vol. 7, no 2/3, pp. 309-311, 1990.

[4] H. A. Buflasa, D. Infield, S. Watson, and M. Thomson, "Wind resource assessment for the kingdom of bahrain," Wind Engineering, vol. 32, no. 5, pp. 439-448, 2008.

[5] H. A. Buflasa, D. Infield, S. Watson, and M. Thomson, "Feasibility study of wind power in the kingdom of Bahrain," in Proc. Wind Energy conference, 2007

[6] G. M. Feregh, "Wind energy potential in Bahrain," Energy conservation and Management, vol. 34, no. 6, pp. 499-506, 1996.

[7] S. M. A. H. EI-Mansy Moustafa, A. Eliman, and H. Zewen, "Operational strategies for kuwait's $100 \mathrm{~kW}_{\mathrm{e}} / 0.7 \mathrm{Mw}_{\text {th }}$ solar power plant," Solar Energy, vol. 34, no. 3, 231-238, 1985.

[8] M. Ramadan and A. Naseeb, "The cost benefit analysis of implementing photovoltaic solar system in the state of Kuwait," Renewable Energy, vol. 36, no. 4, pp. 1272-1276, 2011.

[9] P. S. Solanki, V. S. Mallela, and C.-K. Zhou, "Estimation and diminution of $\mathrm{Co}_{2}$ emissions by clean development mechanism option at power sector in Oman," International Journal of Energy and environment, vol. 4, issue 4, pp. 641-652, 2013.

[10] A. H. Al-Badi, M. H. Albadi, A. M. Al-Lawati, and A. S. Malik, "Economic perspective of PV electricity in Oman," Int. Journal Journal of Energy, vol. 36, no. 1, pp. 226-232, 2011.

[11] A. H. Al-Badi, E. F. EI-Saadany, and M. H. Albadi, "Wind to power a new city in Oman," Energy, vol. 34, no. 10, 2009, pp. 1579-1586.

[12] A. Al-Badi, A. Malik, K. Al-Areimi, and Al-Mamari, "Power sector of Oman-Today and Tomorrow," Int. Journal Journal of Renewable and sustainable Energy Review, vol. 13, pp. 2192-2196, 2009.

[13] A. H. Marafia, "Feasibility study of photovoltaic Technology in Qatar," Int. Journal Journal of Renewable Energy, vol. 24, pp. 565-567, 2004.

[14] W. E. Alnaser and A. H. Almohanadi, "Wind and solar energy in Qatar," Energy, vol. 15, no. 10, pp. 931-934, 1990.

[15] S. H. Alawaji, "Evaluation of solar energy Research and its application in SaudiArabia-20years of experience," Int. Journal of Renewable and Sustainable Energy Reviews, vol. 5, pp. 59-77, 2001.

[16] S. H. Alawaji and S. M. Hasnain, "Role of solar energy research in transfering of Technology to Saudi Arabia," Enegy Sources, vol. 21, no. 10 , pp. 923-934, 1999.

[17] N. M. Al-Abbadi, "Wind energy resources assessment for five locations in Saudi Arabia," Int. Journal Journal of Renewable Energy, vol. 30, pp. 1489-1499, 2005.

[18] M. D. Islam, A. A. Alili, I. Kubo, and M. Ohadi, "Measurement of solar energy (Direct Beam Radiation) in Abu Dhabi," Int. Journal of Renewable Energy, vol. 35, pp. 515-519, 2010.

[19] L. E. L. Char and L. Lamont, "Global solar radiation: Multiple on-site Assessments in Abu Dhabi, UAE," Int. Journal Journal of Renewable Energy, no. 35, pp. 1596-1601, 2010.

[20] A. M. Redha, I. Dincer, and M. Gadalla, "Thermodynamic performance Assessment of wind energy system," Int. Journal of Energy, vol. 36, pp. 4002-4010, 2011.

[21] B. N. D. Reichea, "Energy policies of gulf cooperation council (GCC) countries-possibilities and limitations of ecological modernization in rentier states," International journal of Energy Policy, vol. 38, pp. 2395-2403, 2010.

[22] V. V. Theeyattuparampil, O. A. Zarzour, N. Koukouzas, G. Vidican, Y. Al-Saleh, and I. Katsimpardi, "Carbon capture and storage: State of play, challenges and opportunities for the GCC countries," International Journal of Energy Sector Management, vol. 7, iss. 2, pp. 223-242, 2013.

[23] N. Sultan, "Working for a sustainable GCC future: Reflections on policies \& practices," in The GCC Economies: Stepping up to Future Challenges, M. A. Ramady, Ed. Springer: New York, 2012. 
[24] S. Hertzog and G. Luciani, Energy and Sustainability Policies in the GCC. Kuwait Programme on Development, Governance \& Globalisation in the Gulf States, The Centre for the Study of Global Governance, 2009.

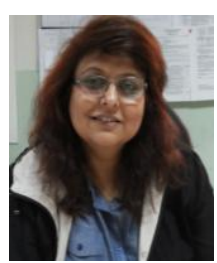

Kavita S. Jerath was born in New Delhi, India. Dr Jerath has done her B.Sc degree in physics from India following with M.Sc degree in physics and doctorate degree in physics again from India. Next, Dr. Jerath completed college teacher's training program in 2009 from Canada. Dr. Jerath's major field of study was $\mathrm{X}$-ray spectroscopy.

With a work experience of 20 years she is currently an associate professor in Bits Pilani Dubai, DIAC, Dubai. She has published 15 papers in journals and international conferences.

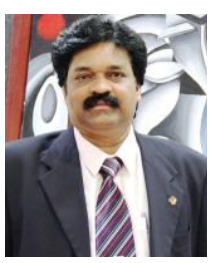

N. K. Millerjothi was born in Chennai, Tamil Nadu, India. Dr. Miller has done B.E degree in mechanical engineering from Anna University, India followed with maintenance management, M.E degree in energy engineering from Anna University, India. Dr. Miller has done Ph.D degree in internal combustion engines from Anna univeristy, India.

His major field of study is energy engineering. He started as a maintenance engineer in Peacock polymers Ltd in 1991 and moved to teaching profession in 2000 as a teaching and research associate in Anna University. He is currently an assistant professor in Bits Pilani Dubai.

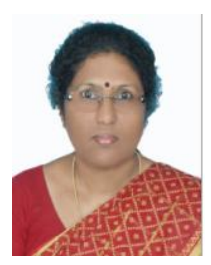

S. Karthiyayini was born in Chennai, India. Dr. Karthiyayini has done her M.Sc, M.Phil, and Ph.D degrees in nuclear physics from India.

Her major field of study is high energy physics, nanomaterials and renewable energy.

She has been in the field of teaching and research for about 25 years. She is currently a professor in Bits Pilani Dubai.

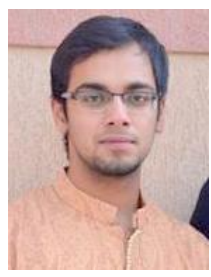

Akshay Sharma was born in New Delhi, India. Mr. Sharma holds a B.E (Hons) electronics \& communication degree from Bits Pilani. 